\title{
An archaeology of lunacy
}

Managing madness in early nineteenth-century asylums

Katherine Fennelly

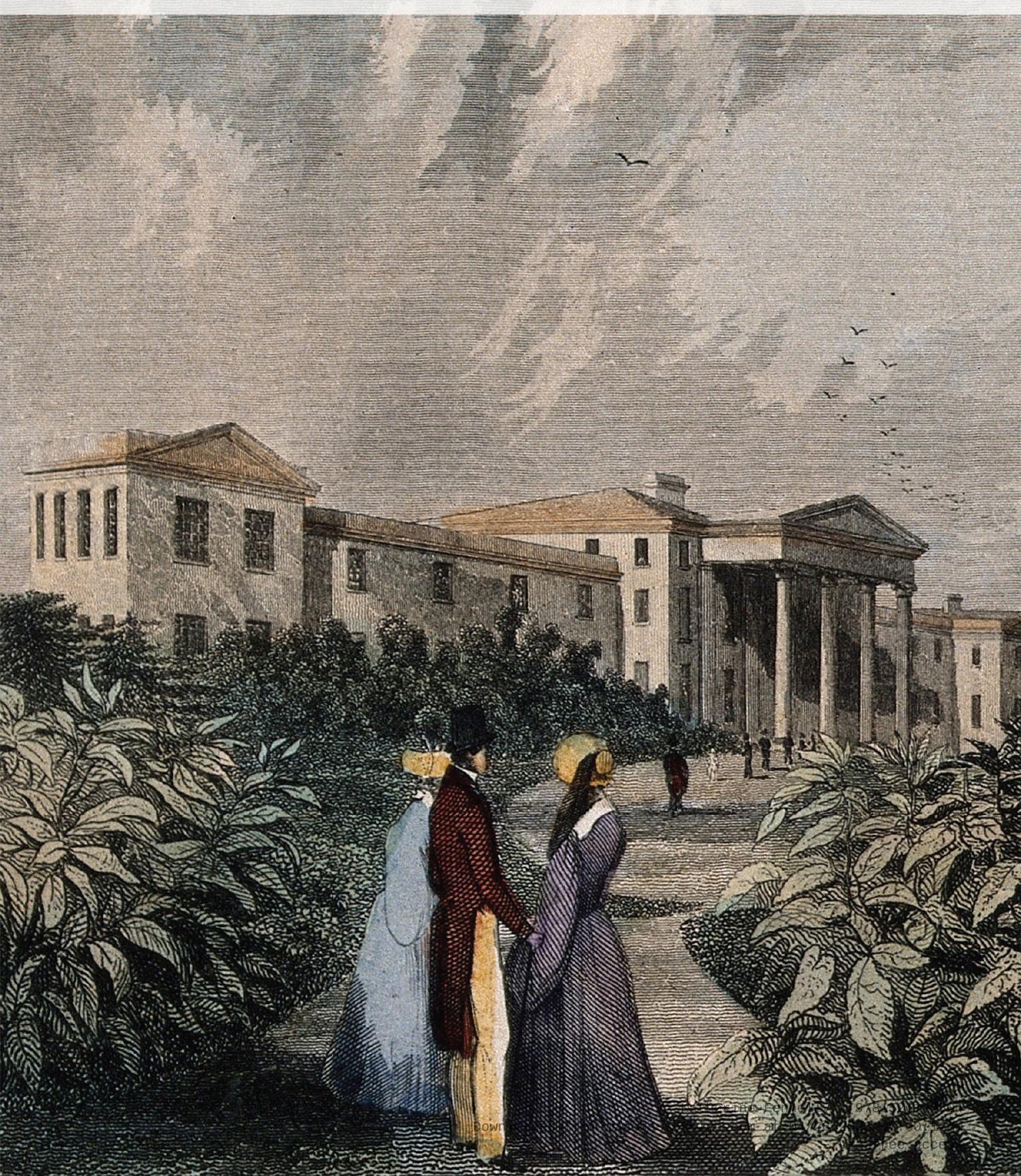


An archaeology of lunacy

MANCHESTER 1824

Manchester University Press 


\title{
Social Archaeology and Material Worlds
}

\author{
Series editors \\ Joshua Pollard and Duncan Sayer
}

Social Archaeology and Material Worlds aims to forefront dynamic and cutting-edge social approaches to archaeology. It brings together volumes about past people, social and material relations and landscape as explored through an archaeological lens. Topics covered may include memory, performance, identity, gender, life course, communities, materiality, landscape and archaeological politics and ethnography. The temporal scope runs from prehistory to the recent past, while the series' geographical scope is global. Books in this series bring innovative, interpretive approaches to important social questions within archaeology. Interdisciplinary methods which use up-to-date science, history or both, in combination with good theoretical insight, are encouraged. The series aims to publish research monographs and well-focused edited volumes that explore dynamic and complex questions, the why, how and who of archaeological research.

\section{Previously published}

Neolithic cave burials: Agency, structure and environment Rick Peterson

The Irish tower house: Society, economy and environment, c. 1300-1650 Victoria L. McAlister

\section{Forthcoming}

Images in the making: Art, process, archaeology

Ing-Marie Back Danielsson and Andrew Meirion Jones (eds)

Communities and knowledge production in archaeology

Julia Roberts, Kathleen Sheppard, Jonathan Trigg and Ulf Hansson (eds)

Early Anglo-Saxon cemeteries: Kinship, community and mortuary space

Duncan Sayer

$$
\begin{gathered}
\text { Urban Zooarchaeology } \\
\text { James Morris }
\end{gathered}
$$

An archaeology of innovation: Approaching social and technological change in human society

Catherine J. Frieman 


\title{
An archaeology of lunacy
}

\author{
Managing madness \\ in early nineteenth-century asylums
}

Katherine Fennelly

Manchester University Press 
Copyright $@$ C Katherine Fennelly 2019

The right of Katherine Fennelly to be identified as the author of this work has been asserted by her in accordance with the Copyright, Designs and Patents Act 1988.

Published by Manchester University Press

Altrincham Street, Manchester M1 7JA

www.manchesteruniversitypress.co.uk

British Library Cataloguing-in-Publication Data

A catalogue record for this book is available from the British Library

ISBN 9781526126498 hardback

First published 2019

The publisher has no responsibility for the persistence or accuracy of URLs for any external or third-party internet websites referred to in this book, and does not guarantee that any content on such websites is, or will remain, accurate or appropriate.

Typeset in 10.5/12.5 Sabon LT Std by

Servis Filmsetting Ltd, Stockport, Cheshire 